\title{
Situation of Rural Health Care: A Study of Thoubal District, Manipur
}

\author{
Md. Riyas Sheikh \\ Social Work, CMJ University, Shillong, India
}

\begin{abstract}
S: The constitution of India recognizes the Government responsibility for health and states that "The state shall regard the raising of the level of nutrition and the standard of living of its people and the improvement of public health as among its primary duties". The preamble of to the WHO constitution states: "The enjoyment of the highest attainable standard of health is one of the fundamental rights of every human being without distinction of race, religion, political belief, economic and social condition". Srabanti Mukherjee (2010) describes the unless one is fobbed off by the displays of hi-tech medical care and use of state of the art medical technologies in five star deluxe facilities of a few select urban centre's, the tale of utter helplessness and callous carelessness is so apparent that it is now frequently taken as a matter of course. The blatantly paradoxical spectacle of buying and selling of health improvements as consumer goods by the well off minority in the metros on the one hand and the denial of basic health facilities to the vast majority of the rural population along the length and breadth of the country on the other hardly evokes any comment. The access to healthy living conditions and access to quality health care for all citizens are not only the basic human rights, but also essential prerequisites for socio-economic development. A large section of the poor avoids treatment due to extreme poverty. Apart from poverty, there are other factors responsible for limited access to health care like availability of health care infrastructure and work force. In addition to these, some social and psychological factors of the rural populace are also responsible for avoiding health care.
\end{abstract}

Keywords: WHO, Health Care, NRHM, Thoubal District.

\section{INTRODUCTION}

Health is not perceived in the same way by biomedical scientists, social science specialists, health specialists, health care providers and this give rise to confusion about the concept of health by the WHO defined "Health is a state of complete physical, mental and social well being and not merely an absence of diseases or infirmity". The desire for survival in human beings drives the need for healthcare. Policies and strategies for health care system may differ from country, even from region to region. However one common goal across many countries is to form a sustainable health care system is accessible and affordable to every citizen. Strategies to achieve this goal however are not clear and simple. There have been overlapping generations of healthcare system reform during the $20^{\text {th }}$ century. However, there are no universal solutions, and no country has achieved an ideal model (Feachem 2000; Kawabatta 2000). One model employed in many socialist countries was universal, free health care. This was centralized, state controlled model originating in the former USSR. It was maintained for decades but collapsed in those countries that employed it just 10 years after the Alma-Ata conference in 1978, at which WHO/UNICEF launched an international strategy of primary health care for achieving the goal of "Health for All by the year 2000". In the last decades many countries regardless of socioeconomic status, embarked on health care system reform with a new vision. Accessible is needed as to what currently

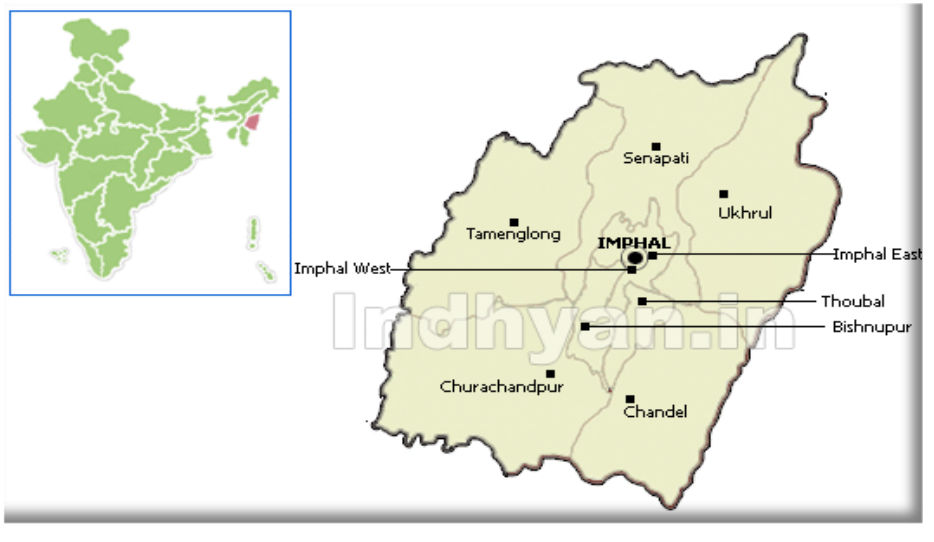
works in healthcare, what should be maintained, what yields healthcare benefits and what should either be discarded. New approaches are needed to address the many and varied future challenges. The Government of India adopted a National Health policy in August 1983. India is one of the few countries in the world to have come out with a national policy on health. The present health situation in India is far from satisfactory. All efforts have to be made to achieve the health goals set for 2000.A.D. It is beyond any doubt that, the wealth of a country is judged by the health of its people. Most of the countries in the world are seeking viable answers to the question of how to offer a health care system, which leads to universal access to health care for their citizens. 
World watching Rural Health Mission: Sir Andrew, Director, London School of Hygiene and Tropical Health "What happens in India in the primary health sector will be crucial". (The Hindu: 11: 2009) Admittance of healthy living conditions and good quality health is not only fundamental rights for each and every Indian, but also crucial factor for socio-economic maturity of the nation. The country's policy towards health has been traditionally identified by the provision of primary healthcare as the states responsibility. The policy also encouraged the establishment of the countrywide, state run primary healthcare infrastructure. The policy has remained silent on the role of the private sector in provision of healthcare. Notwithstanding to this, the private health care sectors have developed to meet increasing demand for health care services. The following objectives to achieve the strategies:

(i). To measure the facilities of public health care services.

(ii). To avail the health care institutions \& accessible the primary health care.

(iii). To create awareness the right to health on primary health care.

(iv). To involve on the principle of community participation in the primary health care.

(v). To evaluate the quality of service by health care provider's to the communities.

(vi). To study the minority and inequalities in healthcare.

\section{HEALTH PROFILE IN MANIPUR}

The present health profile of Manipur with reference to life expectancy, mortality patterns, and access preventive and curative care. However, large gaps in data limited the analysis. Relevant census 2001 data were not available. National health and Family Survey (NFHS), a standard source of data on health data for the country, has not collected data for the northeastern states, including Manipur. The Sample Registration Survey (SRS) too has no recent and relevant data on the state. Despite the gaps in information, existing sources show that Manipur enjoys relatively good public health indicators. Good individual and population health is influenced by material well being, which UNDP described as access to the income and assets required to lead a decent standard of living. The absence of technological progress agriculture, transformation on the selfcontained tribal economy, and reduction in the carrying capacity of the land due to population pressure has together resulted in poverty in the area. Despite the low level of material well, the state has an impressive record on select public health indicators. According to the National Human development Report (2001; 79-79), Manipur had the lowest infant mortality rate in the country from as early as 1981.

\begin{tabular}{|c|c|c|c|c|c|c|c|c|c|}
\hline \multicolumn{10}{|c|}{ Table 1: KEY HEALTH INDICATORS FROM NFHS-3 IN MANIPUR, INDIA } \\
\hline \multirow{3}{*}{$\begin{array}{l}\text { Key Indicators } \\
\text { from NFHS-3 }\end{array}$} & \multirow{3}{*}{$\begin{array}{l}\text { NFHS-3 } \\
(2005- \\
06)\end{array}$} & \multicolumn{2}{|c|}{ Residence } & \multicolumn{4}{|c|}{ Education } & \multirow{3}{*}{$\begin{array}{l}\text { NFH } \\
\text { S-2 } \\
(1998 \\
-99)\end{array}$} & \multirow{3}{*}{$\begin{array}{l}\text { NFH } \\
\text { S-1 } \\
(1992 \\
-93)\end{array}$} \\
\hline & & & & \multirow{2}{*}{$\begin{array}{l}\text { No } \\
\text { educatio } \\
\mathrm{n}\end{array}$} & \multirow{2}{*}{$\begin{array}{l}5 \\
\text { years } \\
\text { compl } \\
\text { ete }\end{array}$} & \multirow{2}{*}{$\begin{array}{l}5-9 \\
\text { years } \\
\text { Comple } \\
\text { te }\end{array}$} & \multirow{2}{*}{$\begin{array}{l}10 \\
\text { years } \\
\text { complet } \\
\text { e and } \\
\text { above }\end{array}$} & & \\
\hline & & Urban & $\begin{array}{l}\text { Rur } \\
\text { al }\end{array}$ & & & & & & \\
\hline \multicolumn{10}{|c|}{ Marriage and Fertility } \\
\hline $\begin{array}{l}\text { 1. Women age } \\
20-24 \text { married by } \\
\text { age } 18(\%)\end{array}$ & 12.9 & 11.7 & 13.5 & 29.5 & $(23.9)$ & 16.7 & 2.5 & 9.9 & 14.3 \\
\hline $\begin{array}{l}\text { 2. Men age } 25- \\
29 \text { married by } \\
\text { age } 21(\%)\end{array}$ & 11.6 & 9.2 & 12.9 & * & $(17.8)$ & 18.6 & 5.5 & na & $\mathrm{Na}$ \\
\hline $\begin{array}{l}\text { 3. Total fertility } \\
\text { rate (children per } \\
\text { woman) }\end{array}$ & 2.8 & 2.4 & 3.1 & 3.7 & 3.4 & 2.9 & 2.5 & 3.0 & 2.8 \\
\hline $\begin{array}{l}\text { 4. Women age } \\
15-19 \text { who were } \\
\text { already mothers } \\
\text { or pregnant at } \\
\text { the time of the } \\
\text { survey }(\%)\end{array}$ & 7.3 & 4.2 & 8.6 & 25.4 & 11.9 & 5.6 & 3.8 & na & na \\
\hline $\begin{array}{l}\text { 5. Median age at } \\
\text { first birth for } \\
\text { women age } 25- \\
49\end{array}$ & 23.7 & $\geq 25$ & 22.9 & 21.0 & 21.7 & 22.3 & $\geq 25$ & 23.1 & 22.4 \\
\hline
\end{tabular}


Situation of Rural Health Care: A Study of Thoubal District, Manipur

\begin{tabular}{|c|c|c|c|c|c|c|c|c|c|}
\hline $\begin{array}{l}6 . \text { Married } \\
\text { women with } 2 \\
\text { living children } \\
\text { wanting no more } \\
\text { children1 }(\%)\end{array}$ & "66.1 & 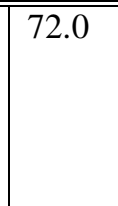 & "63.0 & 64.4 & "53.2 & 65.1 & $\overline{c 70.6}$ & "45.6 & 39.5 \\
\hline 6a. Two sons & 68.8 & 81.0 & 62.1 & $(65.6)$ & $*$ & (71.9) & 75.1 & na & $\mathrm{Na}$ \\
\hline $\begin{array}{l}\text { 6b. One son, one } \\
\text { daughter }\end{array}$ & 76.2 & 76.4 & 76.0 & 74.9 & $*$ & 75.1 & 79.1 & na & $\mathrm{Na}$ \\
\hline $\begin{array}{l}6 c . \text { Two } \\
\text { daughters }\end{array}$ & 24.3 & $(35.0)$ & 19.6 & $*$ & $*$ & $(17.8)$ & $(28.2)$ & na & na \\
\hline \multicolumn{10}{|c|}{$\begin{array}{l}\text { Family Planning (currently married women, age 15-49) } \\
\text { Current use }\end{array}$} \\
\hline 7. Any method (\%) & \begin{tabular}{l|l} 
& 48.7
\end{tabular} & 54.5 & 46.0 & 43.2 & 48.6 & 50.8 & 51.9 & 38.7 & \begin{tabular}{|l|}
34.9 \\
\end{tabular} \\
\hline $\begin{array}{l}\text { 8. Any modern } \\
\text { method }(\%)\end{array}$ & 23.6 & 24.8 & 23.0 & 23.9 & 22.1 & 25.1 & 22.3 & 25.9 & 24.1 \\
\hline $\begin{array}{l}\text { 8a. Female } \\
\text { sterilization }(\%)\end{array}$ & 8.2 & 8.9 & 7.9 & 11.9 & 11.0 & 6.4 & 5.6 & 14.4 & 10.9 \\
\hline $\begin{array}{l}\text { 8b. Male sterilizatic } \\
(\%)\end{array}$ & \begin{tabular}{l|l} 
on & 0.5 \\
\end{tabular} & 0.6 & 0.4 & 0.3 & 0.5 & 0.6 & 0.6 & 1.1 & 2.9 \\
\hline 8c. IUD (\%) & 5.3 & 4.0 & 5.9 & 4.1 & 4.4 & 7.0 & 5.1 & 6.8 & 6.7 \\
\hline 8d. Pill (\%) & 5.3 & 4.7 & 5.6 & 5.5 & 4.8 & 6.8 & 3.8 & 2.2 & 2.4 \\
\hline 8e. Condom (\%) & 4.1 & 6.4 & 3.1 & 2.0 & 1.5 & 4.1 & 7.0 & 1.3 & 1.2 \\
\hline \multicolumn{10}{|c|}{$\begin{array}{l}\text { Maternal and Child Health } \\
\text { Maternity care (for births in the last } 3 \text { years) }\end{array}$} \\
\hline $\begin{array}{l}\text { 10. Mothers who ha } \\
\text { at least } 3 \text { antenatal } \\
\text { care visits for their } \\
\text { last birth (\%) }\end{array}$ & \begin{tabular}{l|l}
$\mathrm{ad}$ & 70.1 \\
\end{tabular} & 85.9 & 64.0 & 45.7 & 52.4 & 75.5 & 86.6 & 54.7 & 41.3 \\
\hline $\begin{array}{l}\text { 11. Mothers who } \\
\text { consumed IFA for } \\
90 \text { days or more } \\
\text { when they were } \\
\text { pregnant with their } \\
\text { last child }(\%)\end{array}$ & 13.9 & 21.8 & 4.2 & 4.2 & 8.9 & 11.7 & 24.3 & na & na \\
\hline $\begin{array}{l}\text { 12. Births assisted } \mathrm{l} \\
\text { a } \\
\text { doctor/nurse/LHV/f } \\
\text { NM/other health } \\
\text { personnel (\%) }\end{array}$ & \begin{tabular}{l|l} 
by & 61.7 \\
A & \\
\end{tabular} & 85.2 & 52.8 & 34.5 & 43.3 & 65.4 & 82.6 & 53.9 & 39.9 \\
\hline $\begin{array}{l}\text { 13. Institutional } \\
\text { births }(\%)\end{array}$ & 49.3 & 71.2 & 40.9 & 22.5 & 32.9 & 49.3 & 73.1 & 34.5 & 23.0 \\
\hline $\begin{array}{l}\text { 14. Mothers who } \\
\text { received postnatal } \\
\text { care from a } \\
\text { doctor/nurse/LHV/t } \\
\text { NM/other health } \\
\text { personnel within } 2 \\
\text { days of delivery for } \\
\text { their last birth (\%) }\end{array}$ & A & 70.1 & 40.9 & 24.4 & 31.4 & 47.5 & 73.2 & na & na \\
\hline \multicolumn{10}{|c|}{$\begin{array}{l}\text { na : Not available } \\
\text { ( ) Based on } 25-49 \text { unweighted cases } \\
\text { * Based on fewer than } 25 \text { unweighted cases } \\
1 \text { Excludes pregnant women. } \\
2 \text { Based on the last } 2 \text { births in the } 3 \text { years before the survey to ever-married women. } \\
3 \text { Based on WHO standard. }\end{array}$} \\
\hline
\end{tabular}

The National Rural Health Mission (NRHM) is being operationalized from April 2005 throughout the country, with special focus on 18 States which include 8 Empowered Action Group (EAG) States, 8 North-East States, Himachal Pradesh and Jammu \& Kashmir, where the health infrastructure is weak. The same was launched in the North -Eastern States including Manipur in November 2005. The main aim of NRHM is to 
provide accessible, affordable, accountable, effective and reliable primary health care, especially, to the poor and vulnerable sections of the population. It also aims at bridging the gap in Rural Health Care through creation of a cadre of Accredited Social Health activists (ASHA), improved hospital care measured through Indian Public Health Standards (IPHS), decentralization of program to district level to improve intra- and inter-sectoral convergence and effective utilization of resources. The NRHM further aims to provide overarching umbrella to the existing programs of Health and Family Welfare including RCH-II, Malaria, Blindness, Iodine deficiency, TB, Leprosy and Integrated Disease Surveillance. Further, it addresses the issue of Health in the context of sector-wise approach addressing sanitation and hygiene, nutrition and safe drinking water as basic determinants of good health in order to have greater convergence among the related social sector Departments i.e. AYUSH, Women and Child Development, Sanitation, Elementary Education, Panchayati Raj and Rural Development. The Mission further seeks to build greater ownership of the program among the community through involvement of Panchayati Raj Institutions, NGOs and other stake-holders at National, State, District and Subdistrict levels to achieve the goals of National Population Policy and national Health Policy. The key components of the Mission are: (i) Creation of a cadre of voluntary, female Accredited Social Health Activists (ASHA) at village level. (ii) Creation of Village Health Team and preparation of Village Health Plan (iii) Strengthening Sub-Centre's with Untied Funds of Rs. 10,000/- per annum. (iv) Raising Community Health Centre's and Primary Health Centre's to levels of Indian Public Health Standards. (v) Integrating vertical Health and Family Welfare programs and societies under NRHM at National, State, and district levels. (vi) Strengthening Program Management Capacities at National, State, District \& Block levels. (vii) Institutionalizing district level management of health. (viii) Supply of generic drugs (both allopathic and AYUSH) to Sub-centre's/PHC's/CHC's.

\section{STATUS OF HEALTH CARE SYSTEM IN THOUBAL DISTRICT}

The status of health care system in Thoubal district from a separate vista. Not only health system other system of any developmental fields is also poor. Under the guidelines of National Rural Health Mission, Government of India, District Health Society, Thoubal was formed in the month of August, 2006 and registered under the Manipur Societies Registration Act, 1989. As a District Apex Body, Thoubal has registered District Health Society under the Chairmanship of Deputy Commissioner, Thoubal. Under this body there are registered 1(one) no. of Hospital Management Society - District Hospital (DH), 5 (five) nos. of Hospital Management Society - Community Health Centre's (CHC), 12 (twelve) nos. of Hospital Management Society - Primary Health Centre's (PHC). Over and above DHS, Thoubal have 50 (fifty) nos. of Sub-Centre Development Committee - Primary health Sub-Centre (PHSC) and 500 (five hundred) Village Health Sanitation \& Nutrition Committee (VHNSC) also headed by PRI members.

The minority Muslims community in this district, but they haven't knowledge and aware about the primary health care services. The study identified that the critical areas of scope concerns in Thoubal District Health Care system are mainly, availability, accessibility and affordability of health services on maternal \& child health through the health care issues i.e. life expectancy, mortality, nutrition, high prevalence of diseases, poor sanitation, inadequate safe drinking water and healthcare infrastructure. The need for prioritizing health care particularly from the prevention, promotion and curative aspect is to be considered. According to a study in the state health policy is essential for redressing increase of practice private health facilities by health care provider's impact on absenteeism, increase of salary without performance of service delivery, lack of decentralization \& community participation and ownership the growing disparity in health care facilities in Thoubal district. To improve the health services in the study areas, the village community through PRIs needs to be involved in the supervision and functioning of the whole system to make accountable to users. According to Sachar Committee Report (SRC), the health of Muslims, especially women, is directly linked to poverty and the absence of basic services like clean drinking water and sanitation - leading to malnutrition, anemia, a variety of diseases and poor life expectancy. In the Thoubal district, Muslims communities are the most populated. In conflict prone
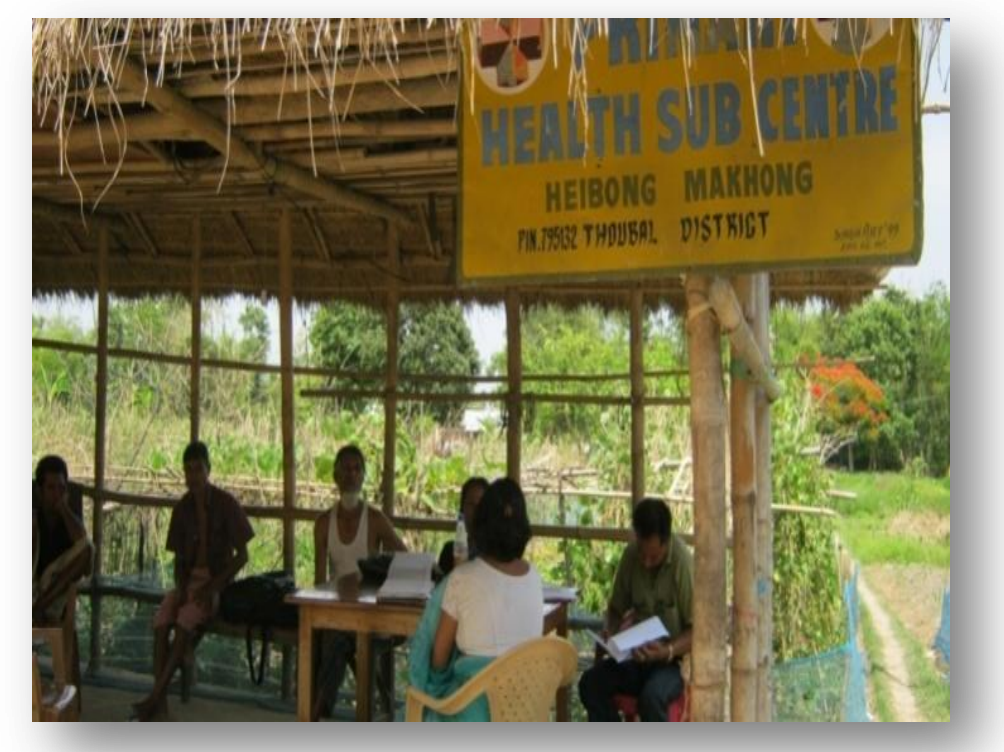
areas there is alarming evidence of a host of psychosocial problems, including stress, depression, and posttraumatic disorders among women. Health services for women living in Muslim concentration areas are much worse than for women from other SRCs. Even primary health facilities are available only at long distances. Unacceptable behavior that many Muslim women encounter at public health centres discourages them from going there. They prefer local health care providers from their own community, particularly for gynecological problems, even though they may not be as qualified. This hesitation on the part of the Muslim women to access public health facilities often leads to their exploitation by private doctors. The few health care centers are staffed by women doctors are concentrated in urban areas, forcing rural populations to survive with virtually no public health care.

\section{RESULTS}

The major health problems are: (i) The lack of health care facilities are concentrated about $80 \%$ in urban areas where only $20 \%$ population resides, resulting in gross unavailability of health care support in the rural area (The Hindu). (ii) On average more than one third of the service providers personnel were observed missing during hours. Absentees were as high as $40 \%$ among doctors while in five categories of health service providers. (iii) Uncontrolled fertility directly threatens the health of mothers and infants and may undermine the health of other family members as well. (iv) High prevalence of communicable diseases includes malaria, leprosy, TB, viral hepatitis, enteric fever \& RTI/ STI etc. They account for a very high rate of morbidity and mortality.

\begin{tabular}{|c|c|c|c|c|c|c|c|c|c|c|}
\hline \multicolumn{11}{|c|}{$\begin{array}{l}\text { : AVAILABILITY OF HEALTH FACILITY \& HEALTH PERSONNEL IN TH } \\
\text { CT } \\
\text { age of availabilities of facility and health personnel of villages by Thoubal, 2007-08 }\end{array}$} \\
\hline & $\begin{array}{l}\text { Sub } \\
\text { centr } \\
\text { e }\end{array}$ & $\begin{array}{l}\text { PHC } \\
\mathrm{s}\end{array}$ & \begin{tabular}{|l|} 
Any \\
Govt. \\
Healt \\
h \\
facilit \\
y 1
\end{tabular} & $\begin{array}{l}\text { Doct } \\
\text { or }\end{array}$ & $\begin{array}{l}\text { ASH } \\
\text { A }\end{array}$ & $\begin{array}{l}\text { Anganwa } \\
\text { di } \\
\text { Workers }\end{array}$ & $\begin{array}{l}\text { JSY } \\
\text { beneficia } \\
\text { ry }\end{array}$ & $\begin{array}{l}\text { VHSN } \\
\text { C }\end{array}$ & $\begin{array}{l}\text { Awar } \\
\mathrm{e} \text { of } \\
\text { Untie } \\
\mathrm{d} \\
\text { fund } \\
2\end{array}$ & $\begin{array}{l}\text { Numb } \\
\text { er of } \\
\text { village } \\
\text { s }\end{array}$ \\
\hline $\begin{array}{l}\text { Thoub } \\
\text { al } \\
\text { Distri } \\
\text { ct }\end{array}$ & 34.4 & 15.6 & 53.1 & 9.4 & 84.4 & 96.9 & 50.0 & 28.1 & 37.5 & 32 \\
\hline $\begin{array}{l}\text { Manip } \\
\text { ur }\end{array}$ & 28.4 & 10.3 & 39.3 & 6.3 & 72.5 & 93.4 & 30.1 & 25.8 & 30.9 & 349 \\
\hline \multicolumn{11}{|c|}{$\begin{array}{l}\text { ** Facilities as reported by village pradhan/up pradhan/any other panchayat member/teacher/gram } \\
\text { sevak/aganwadi worker. } 1 \text { Includes Sub-Centre, Primary Health } \\
\text { Centre (including Block PHC), Community Health Centre or referral hospital, government hospital, } \\
\text { and government dispensary within the village. } 2 \text { This information } \\
\text { was collected from Sarpanch/Pradhan, PRI member, Gram Sevak, Village Secretary/officer or any } \\
\text { other official at village level. } \\
\text { VHSNC = Village Health Sanitation and Nutrition Committee. } \\
\text { Note: Table is based on unweighted cases. }\end{array}$} \\
\hline
\end{tabular}

\section{Table 3: COMPLICATIONS DURING PREGNANCY, DELIVERY AND POST DELIVERY PERIOD BY THOUBAL DISTRICT}

Percentage of women (aged 15-49) \# who had pregnancy, delivery, post-delivery complications and treatment seeking

behaviour by Thoubal district, Manipur, 2007-08

\begin{tabular}{|l|l|l|l|l|l|l|}
\hline & \multicolumn{5}{|c|}{ Percentage of women1 } \\
\hline & $\begin{array}{l}\text { Who had } \\
\text { complication } \\
\text { during } \\
\text { pregnancy }\end{array}$ & $\begin{array}{l}\text { Sought } \\
\text { treatment for } \\
\text { pregnancy } \\
\text { complication2 }\end{array}$ & $\begin{array}{l}\text { Who had } \\
\text { delivery } \\
\text { complication }\end{array}$ & $\begin{array}{l}\text { Who had } \\
\text { post- } \\
\text { delivery } \\
\text { complication }\end{array}$ & $\begin{array}{l}\text { Sought } \\
\text { treatment for } \\
\text { post-delivery } \\
\text { complication3 }\end{array}$ & $\begin{array}{l}\text { Number } \\
\text { of } \\
\text { women** }\end{array}$ \\
\hline $\begin{array}{l}\text { Thoubal } \\
\text { District }\end{array}$ & 35.0 & 78.3 & 26.4 & 20.2 & 47.3 & 401 \\
\hline Manipur & 33.5 & 56.5 & 25.6 & 18.8 & 36.2 & 3531 \\
\hline
\end{tabular}


\# Women who had their last live/still birth since 01-01-2004.

** Unweighted cases.

1 Women who had last live/still birth during three years preceding the survey.

2 Women who reported at least one complication of pregnancy.

3 Women who reported at least one post delivery complication.

\section{CONCLUSION}

There is need to minimize health service providers' practice at private hospitals/ facility by health service providers i.e. physicians \& nurses etc., decentralization of services, community participation and involvement and eliminated absenteeism for health service providers at their health institution. Further, it leads to make a Healthy Family, Healthy Villages, Healthy Societies \& Healthy Nation

\section{Acknowledgement}

I would like to offer my deepest sense of gratitude to my Professor and Research Supervisor Dr. S. Romeobala Devi, Principal, College of Social Work, Imphal, Manipur University for giving valuable suggestion and supervising the entire work.

\section{Journal Papers:}

\section{References}

[1] Journal, Health Policy \& Planning May 2011, London.

[2] Newsletter NRHM, Ministry of Health \& Family Welfare, GOI, Delhi.

[3] Newsletter NRHM, State Health Society, Manipur.

[4] Prabhavathy.P \& Dr.S.N.Mahalakshmi, ELT with specific regard to Humanistic Approach, ISSN: 2279-0845 Volume 1, Issue (July-August 2012), PP 38-39

[5] Sanjukta Ghosh, Planning For Baruipur District Headquarters - A Future Growth Node in the Kolkata Metropolitan Area By 2025, ISSN: 2279-0845 Volume 1, Issue 1 (July-August 2012), PP 09-13.

\section{Reports:}

[6] MOBC, Survey Report for Meitei Pangal, DIPR, Imphal, 2004.

[7] Prime Minister Office, Report on the Social, Economic \& Educational status of the Muslim Community of India, New Delhi, $9^{\text {th }}$ March 2005

[8] Sachar Committee, Ministry/ Department wise implementation on the follow-up action, New Delhi, $31^{\text {st }}$ March 2010 .

\section{Books:}

[9] Kumar Avanish, Human Right to Health, Satyam Law International, New Delhi, 2007.

[10] Sarkar Ashok Kumar, NGOs the new lexicon of Health Care, Concept Publishing. 